\title{
ヒト胎児声門下腔粘膜上皮の電顕的研究
}

酒井昇, 未永通
田中克彦, 寺山吉彦

\section{Electron Microscopic Study on the Subglottic Mucosa in Human Fetuses}

Noboru Sakai, M.D., Tohru Suenaga, M.D., Katsuhiko Tanaka, M.D., and Yoshihiko Terayama, M.D.

Department of Otorhinolaryngology, Hokkaido University School of Medicine, Sapporo

The differentiation of the subglottic mucosa in human fetuses has been studied only by light microscopy. We observed for the first time the development of human subglottic mucosa from the 8th to the 21st week of gestation by scanning as well as transmission electron microscopies, and could obtain the following conclusions:

1. Ciliated cells and goblet cells appeared at the 12 th week of gestation that was similar to the previous reports, and the detailed cytodifferentiation of both cells could be observed.

2. We could demonstrate for the first time that primary cilia appeared in the subglottic mucosa at the 10th week of gestation. Among these primary cilia, very long ones were observed and were supposed to be the grown forms of short primary cilia.

3. Glycogen granules in non-ciliated cells were observed in parallel with the cell differentiation, so they were seemed to be the source of energy necessary for the cell differentiation.

Key words : human fetuses, subglottic mucosa, electron microscopy, cytodifferentiation

\section{I 。緒言}

声門下腔粘膜上皮は成人の場合，多列線毛円 柱上皮とされている。ところでヒト胎児の声門 下腔粘膜上皮の分化過程に関してはこれまで勝 谷 ${ }^{1)}$, 横手 ${ }^{21}$, 井上 ${ }^{3)}$ らにより光顕的観察が行われ ているが, 超微形態学的研究は行われていない。 今回われわれは胎齢 8 週より21週までのヒト胎 児の声門下腔粘膜上皮を走查型および透過型電 顕で観察し，若干の知見を得たので報告する。

北海道大学医学部耳鼻咽喉科学教室

別刷請求： $\mathbf{\Upsilon} 060$ 北海道札幌市北区北15条西 7 丁目 北海道大学医学部耳鼻咽喉科学教室 酒井 昇

投稿受付：1988年11月24日

\section{II . 研究材料および方法}

観察材料は，死後 4 時間以内の人工流産によ って得られたヒト胎児 7 例である。それらの胎 齢は，8，10，12，14，16，18，21週で，胎齢の 決定は頂尾長を基にした(表 1 )。頸部より喉頭 を摘出し， $3 \%$ パラフォルムアルデヒド $-0.5 \%$ グルタールアルデヒド混合液に $2 \sim 3$ 時間固定 した後，等張燐酸緩衡液で約 10 分間洗浄した。

表 1 対象例の胎齢と頂尾長

\begin{tabular}{c|c|c|c|c|c|c|c}
\hline $\begin{array}{c}\text { 胎 齢 } \\
\text { (週) }\end{array}$ & 8 & 10 & 12 & 14 & 16 & 18 & 21 \\
\hline $\begin{array}{c}\text { 頂 尾 長 } \\
(\mathrm{mm})\end{array}$ & 30 & 55 & 82 & 114 & 136 & 158 & 200 \\
\hline
\end{tabular}




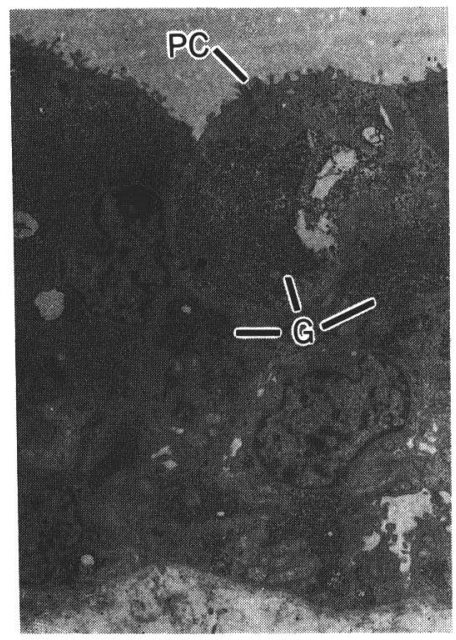

図 1 胎齢10週声門下腔粘膜上皮

PC：primary cilia，G：グリコーゲン顆粒 (3200倍)

次いで喉頭より声門下部を採取して正中で半切 し，それぞれを走査型と透過型電䫓用の試料と した。後固定は $1 \%$ オスミウム酸 1 時間とし, 系列アセトンで脱水後, 透過型電顕試料はケト ール651に包埋した。LKB ultratomeにより薄 切し,トルイジンブルー染色後光顕的に観察し, さらにダイアモンドナイフによる超薄切片を硝 酸鉛と酢酸ウラニールの二重染色を施して，日 立電子顕微鏡 HU12A で観察した。走査型電顕 試料は前述の操作で固定・脱水後, 酢酸イソア ミールで置換し臨界点乾燥後金蒸着し走査電顕 （日立製 S-450）で観察した。なお観察部位は甲 状軟骨下端の高さで側面中央部附近の粘膜上皮 とした。

\section{III. 成}

績

\section{1. 胎齢 8 週および10週}

上皮は約 2 層の立方状細胞からなり, 上皮基 底部には明瞭な基底膜の形成がみられる。各細 胞は細胞内小器管の発達はわずかで, 細胞質内 に多量のグリコーゲン顆粒を含む未熟な形態を 示す。胎齢10週の上皮の一部には primary cilium を有する細胞が認められる(図 1)。Primary cilia を走査電顕でみると, 非常に長いも の (約 $6 \mu$ ) から短いもの（約 $1.5 \mu)$ まで混在 していた。細胞表面は平坦で多数の短い mi-

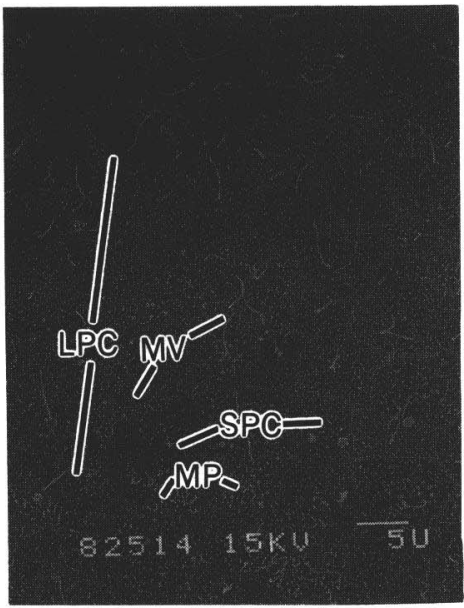

図 2 胎齢 10 週声門下腔粘膜上皮

LPC : 長い primary cilia, SPC : 短い primary cilia, MV : microvilli, MP : microplicae

crovilli と少数の microplicae がみられる（図 $2)$ 。

\section{2. 胎齢12週および14週}

上皮層は多列円柱上皮よりなり, primary cilia は完全に消失し代りにこの時期に初めて 少数の線毛細胞の出現がみられる。線毛細胞は 線毛の密度が少なく, 表面に比較的長い microvilli を有している。またミトコンドリアな どの細胞内小器官は未発達であるが, グリコー ゲン顆粒が認められないのが特徵的であった。 無線毛細胞はやや成熟しグリコーゲン顆粒は減 少している（図 3 ）。上皮表層の細胞の中には, 細胞表面に長い microvilli を有し, 細胞質内に 数個の中心子を含むものがみられる。この細胞 にはグリコーゲン顆粒は認められない（図 4)。 上皮の一部には核上部に典型的な分泌顆粒を有 する杯細胞の出現が初めて認められる。杯細胞 の表面には microvilli, 細胞質内には粗面小胞 体が多数みられる(図 5 )。

\section{3 . 胎齢16週，18週および21週}

上皮層は背の高い多列円柱上皮となり，線毛 細胞や杯細胞は漸次増加する。線毛細胞は線毛 が密生し，その表層には mucous blanket が存 在する。杯細胞の中には分泌顆粒がなく, 細胞 質が暗調を呈するものが認められる。無線毛細 胞にはグリコーゲン顆粒は認められない(図6)。 


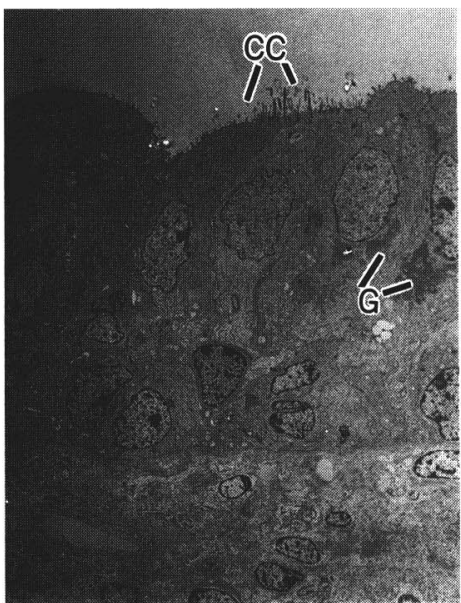

図3 胎齢12週声門下腔粘膜上皮

CC：線毛細胞， G：グリコーゲン顆粒（1200倍）

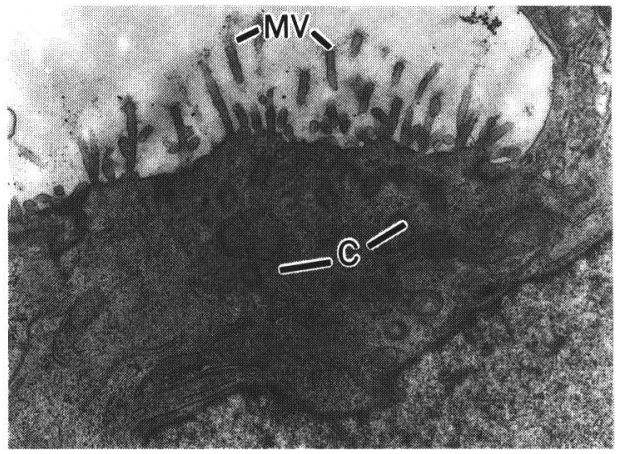

図4 胎齢12週声門下腔粘膜上皮

MV：microvilli, C：中心子 (9000倍)

\section{IV. 総括}

ヒト胎児声門下腔粘膜上皮について経時的に 走查型と透過型電顕で観察した結果, 以下に要 約する所見を得た。

1. 線毛細胞は胎齢12週で初めて認められ, 以後胎齢とともに漸次増加した。

2. Primary cilia は胎柃10週においてのみ みられた。

3. 杯細胞は胎齢 12 週より出現し, それ以降 漸次増加した。

4. 無線毛細胞のグリコーゲン顆粒は胎齢と ともに漸減し, 胎齢 16 週以後は認められなくな った。

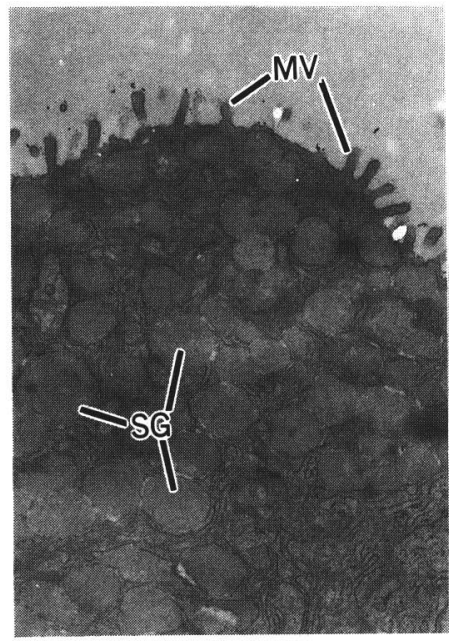

図 5 胎齢 12 週声門下腔粘膜上皮 MV : microvilli, SG：分泌顆粒（9000倍）

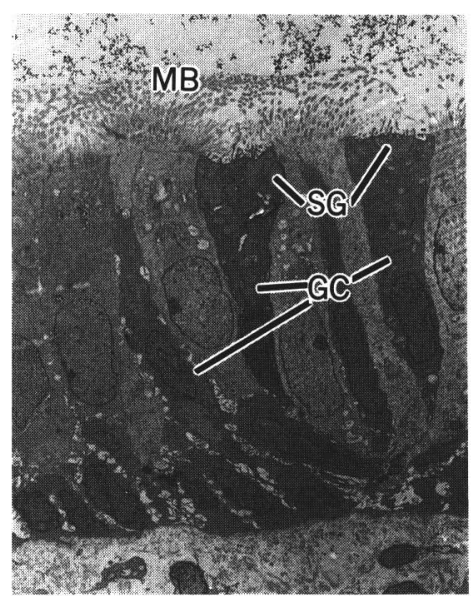

図 6 胎齢 16 週声門下腔粘膜上皮

MB : mucous blanket, GC：杯細胞, SG：分泌顆 粒（1500倍）

表 2 各所見の経時的推移

\begin{tabular}{|c|c|c|c|c|c|c|c|}
\hline & & \multicolumn{2}{|c|}{ 政 (週) } & \multirow[b]{2}{*}{18} & \\
\hline & 8 & 10 & 12 & 14 & 16 & & 21 \\
\hline 線毛細胞 & & & & & & & \\
\hline primary cilia & & 㑹 & & & & & \\
\hline 杯 細 胞 & & & & & & . & \\
\hline グリコーゲン顆粒 & & & & & & & \\
\hline
\end{tabular}


5. 以上の経時的変化についてまとめたのが 表 2 である。

\section{V. 考按}

\section{1. 線毛細胞について}

ヒト胎児声門下腔粘膜上皮における線毛細胞 の出現時期については，光顕的に勝谷 ${ }^{1)}$ が胎齢 11週, 横手2) が12週, 井土 ${ }^{3)}$ が14週であると述べ ている。今回の観察からもほぼ同様の胎齢 12 週 において，幼若ながらも線毛細胞の出現がみら れた。線毛の形成過程に関しては，中心子の分 化に始まり次第にそれらが細胞表面に集まっ て，基底小体に移行して線毛の出芽となること が明らかにされている。われわれの観察でも線 毛発生に先行して，数個の中心子が細胞自由表 面下に集積し，基底小体に移行する像が認めら れ, 従来の報告と同様の線毛発生過程を示す所 見が得られた。胎齢16週においては線毛の先端 に mucous blanketが認められ，すでにこの時 期から線毛運動が開始されていることが推測さ れる。この点に関して大橋6) は, 胎生期家鬼の気 管および鼻中隔粘膜上皮で胎齢26日以後線毛運 動がみられると述べており，七ト胎児声門下腔 粘膜上皮でも線毛運動が行われていることが示 唆される。

\section{Primary cilia について}

胎生期気道粘膜における primary cilia は, 従 来線毛細胞に先行して一時的にみられるとされ ている。この現象は七ト胎児で, 村上8) が下甲介 粘膜, 酒井9 は気管粘膜においてそれぞれみら れたと報告している。ところで，ヒト胎児声門 下腔粘膜に primary ciliaが出現するか否かに ついては,これまでのところ報告されていない。 今回の観察から胎齢 10 週に扔いて, 声門下腔粘 膜にも primary cilia が線毛細胞の出現に先行 してみられることが初めて確認できた。Primary cilia の長さは従来 $2 \mu$ 以下とされている が7,8,10), 今回観察した primary cilia は非常に長 いもの（約 $6 \mu ）$ から短いもの（約 $1.5 \mu ）$ まで 混在していた。これらの長い primary ciliaにつ いては, 酒井 ${ }^{9)}$ がヒト胎児気管粘膜において認 めたとする報告があるのみである。この長い primary cilia は短い primary cilia が発達した 段階のものであると推測され，またヒト以外の
動物で報告されていないのでヒトに特有のもの と考えることができる。Primary cilia を有する 細胞は, 細胞質内に多量のグリコーゲン顆粒を 含む未熟な細胞で, 線毛細胞への移行現象が認 められないことから，胎齢が進むにつれ消失す る運命にあると考えられる。

\section{3. 杯細胞について}

胎生期の喉頭における杯細胞の出現は, 従来 光顕的に声門下腔が最も早く, 胎齢13週でみら れると報告されている ${ }^{2)}$ 。われわれの観察でも ほぼ同様の胎齢12週より典型的な杯細胞を確認 することができた。Kanda ら ${ }^{11)}$ はウサギの胎生 期気管粘膜において，分泌顆粒を有せず細胞質 が他の細胞より暗調を示す細胞を認め,これは 将来の杯細胞になるもので, goblet cell precursorであると述べているが，今回の観察からも 胎齢16週で同様の細胞を見い出すことができ た。

\section{4.グリコーゲン顆粒について}

胎生期の気道上皮細胞にグリコーゲン顆粒が 多量に存在することはよく知られており，七ト 声門下腔粘膜上皮細胞に関しては，横手が，光 顕的に胎齢11週より出現し胎齢15週以後は注と んど消失すると述べている。今回の観察からは 線毛細胞にはグリコーゲン顆粒は認められず, それ以外の無線毛細胞の細胞質に多量のグリコ ーゲン顆粒が含まれているのがわかった。グリ コーゲン顆粒の経時的推移をみると, 胎齢 8 週 より多量にみられ以後胎齢の増加とともに漸減 し, 胎齢16週以降は認められなくなった。 Jordan $^{12)}$ は胎生期にみられるこれらのグリコ ーゲン顆粒の意義について, 細胞の分化に必要 なエネルギー源であると述べている。われわれ の観察では, 細胞の分化が比較的認められない 時期にグリコーゲン顆粒が多く, 細胞の分化が 進むにつれ漸減する点を考え合わせると, Jordanの報告と同様にグリコーゲン顆粒は細胞の 分化に重要な役割を果たしていることが推測さ れる。

\section{VI. 結 語}

胎齢 8 週より21週までのヒト胎児声門下腔粘 膜上皮の分化過程を走查型と透過型電顕で観察 し，以下の結論を得た。 
1. 線毛細胞の出現時期は, 従来の光顕での 報告とほぼ同様の胎齢 12 週であることがわかっ た。また線毛の発育過程の詳細を電顕レベルで 捉えることができた。

2. Primary cilia がヒト胎生期の声門下腔 粘膜上皮においても，胎齢10週で出現すること を初めて証明することができた。Primary cilia の中には他動物に比し非常に長いものが観察で きた。

3．杯細胞は従来の報告と同様の胎齢 12 週よ り出現することがわかった。

4. 無線毛細胞に含まれるグリコーゲン顆粒 は細胞の分化に平行して減少することから，細 胞の分化に必要なエネルギー源と推測された。

\section{文献}

1）勝谷隆夫：日本人胎児に於ける喉頭の発生学的 補遺, 第 1 報, 正常発生. 広大医解剖第一講座 業績集, $6: 53-82,1959$.

2 ) 横手貞護: 日本人喉頭及び気管の発生学的研 究, 第 2 報, 喉頭及び気管㛵成組織の発達につ いて. 長崎医誌, $17: 2588-2655,1939$.

3 ) 井土ふさ：日本人胎児における喉頭粘膜上皮の 発生について。耳鼻臨床，56：341-366, 1963.
4) Leeson, T.S.: The development of the trachea in the rabbit, with particular reference to its fine structure. Anat. Anz., $110: 214-223$, 1961.

5 ) Sorokin, S.P.: Reconstructions of centriole formation and ciliogenesis in mammalian lungs. J. Cell. Sci., $3: 207-230,1968$.

$6 ）$ 大橋淑宏・他：家鬼胎生晚期気道線毛運動の特 殊性に関する機能的ならびに形態学的研究。日 気食会報, $32 ： 422-432,1981$.

7 ) 川端五十鈴, 依田 勝: 気管粘膜上皮に見ら礼る Primary ciliaについて.耳鼻, 21：66-67, 1975 .

8 ）村上忠也：ラットおよびヒトの胎生期における 気道粘膜の分化阔する電顕的研究.耳鼻, 25 ： 1022-1067, 1979.

9 ) 酒井 昇：ヒ卜胎児気管粘膜の電顕的研究. 日気 食会報, $33 ： 254-271,1982$.

10) Kober, H.J. : Die lumenseitige Oberfläche der Rattentrachea während der Ontogenese. Z. Mikrosk. Anat. Forsch., 89: 399-409, 1975.

11) Kanda, T. and Hilding, D. : Development of respiratory tract cilia in fetal rabbits. Acta Otolaryngol., 65 : 611-624, 1968.

12) Jordan, P: Über die Bedeutung des embryonalen Glykogens insbesondere für das Wachstum. Z. Zellforsch., $6: 558-586,1927$. 